\title{
THE ASSESSMENT OF COMMUNITY INTEREST FISH SPECIES FROM PROTECTED AREA ROSCI0229
}

Luiza FLOREA *, Sorin Dorin STR $\breve{T I L} \breve{A} *$ and Mioara COSTACHE **

* “Dunărea de Jos” University of Galaţi, Department of Aquaculture and Environment, Domnească Street 47, Galați, Galați County, România, RO-800008, luizafloreagl@yahoo.com, Sorin.Dorin@ugal.ro ** Nucet Fishery Research Center, Nucet, Brăila Street 218, Dâmbovița County, Romania, RO-137335, scp_nucet@yahoo.com

DOI: 10.1515/trser-2015-0004

KEYWORDS: Siriu, protected area, Cottus gobio, Barbus petenyi, conservation status.

\section{ABSTRACT}

In the protected area ROSCI0229 Siriu were named three fish species of community interest: Gobio uranoscopus frici Vladykov, 1925, Barbus petenyi Heckel, 1847 and Cottus gobio Linné, 1758. Out of 193 fish collected in 2010, 49 were Barbus petenyi and 37 Cottus gobio. In the three monitored rivers (Buzău River, Siriu River, and Crasna River), Barbus petenyi was present in two of them and Cottus gobio was present in all of them. According to the analytical indices of population, frequency, numerical abundance and density we assessed a favorable population status for Barbus petenyi in Buzău River and a medium favorable population status for Cottus gobio in Buzău River and its tributaries Crasna River and Siriu River.

ZUSAMMENFASSUNG: Bewertung der Fischarten von gemeinschaftlichem Interesse im Naturschutzgebiet ROSCI0229 Siriu.

Im Naturschutzgebiet ROSCI0229 Siriu wurden drei Fischarten von gemeinschaftlichem Interesse festgestellt und zwar Gobio uranoscopus frici Vladykov, 1925, Barbus petenyi Heckel, 1847 und Cottus gobio Linné, 1758. Von den 193 im Jahr 2010 gesammelten Individuen von Fischen gehörten 49 zu Barbus petenyi und 37 zu Cottus gobio. In ihrer Verteilung auf die drei untersuchten Fließgewässer (Buzău, Siriu und Crasna) war Barbus petenyi in zweien anzutreffen, während Cottus gobio in allen drei Gewässern vorkam. Gemäß den analytischen Populations-Indices d. h. Frequenz, numerische Abundanz und Dichte, wurde der Zustand der Population im Buzău-Fluss für Barbus petenyi als günstig eingestuft. Für Cottus gobio ist der Zustand der Population für den Buzău und seine beiden Zuflüsse Crasna und Siriu als mittelmäßig zu bewerten.

REZUMAT: Distribuția speciilor de pești de interes conservativ din aria naturală protejată ROSCI0229 Siriu.

În aria naturală protejată ROSCI0229 Siriu au fost semnalate trei specii de pești de interes comunitar: Gobio uranoscopus frici Vladykov, 1925, Barbus petenyi Heckel, 1847 şi Cottus gobio Linné, 1758. Dintr-un număr total de 193 exemplare de pești colectate au fost identificate 49 exemplare de Barbus petenyi și 37 exemplare de Cottus gobio. În cele trei cursuri de apă monitorizate (Buzău, Siriu și Crasna), Barbus petenyi a fost prezentă în două cursuri de apă, iar Cottus gobio în toate trei cursurile de apă. Conform indicilor analitici ai populației, frecvența, abundența numerică și densitatea am evaluat pentru Barbus petenyi statutul populației ca fiind favorabil pentru râul Buzău și pentru Cottus gobio statutul populației ca fiind favorabil mediu pentru râul Buzău și afluenții lui Crasna și Siriu. 


\section{INTRODUCTION}

Biodiversity levels have declined rapidly in Europe over the last few decades (EEA, 2006). The major human pressures upon habitats and species are overexploitation, direct destruction and fragmentation of habitats, changes in abiotic conditions, and introductions of exotic biota (Maiorano et al., 2008; Sax and Gaines, 2008; Thuiller et al., 2005).

To decrease - or better stop - this biodiversity loss, protected areas (PAs) are set aside to conserve habitats and species, and constitute the most widespread instrument used in conservation planning (Margules and Pressey, 2000). Protected areas (PAs) are created for their inherent ecological value (Gaston et al., 2008) and also for their potential to solve social and economic issues faced by local communities (Silva, 2009).

Among the policy instruments that frame the conservation of biodiversity in Europe can be found the European Union's (EU) Habitats Directives (HD) and Birds Directives (BD) (Gaston et al., 2008; Pullin et al., 2009). The Habitats Directive (1992) forms the cornerstone of nature conservation policy in the EU, and together with the older Birds Directive (1979) are the legal base for creating a pan-European protected areas network - the Natura 2000 Network (N2K) - that will facilitate the protection of species and habitats of European conservation interest (Fontaine et al., 2007). This network is composed of all Special Protection Areas (SPAs for the BD) and Sites of Community Importance (SCIs for the HD). All the 5,242 terrestrial SPAs, that coverage $547,819 \mathrm{~km}^{2}$ of European Union's territory (11.1\%) and all the 22,419 terrestrial SCIs, that coverage 719,992 $\mathrm{km}^{2}$ of European Union's territory (13.6\%) form the Natura 2000 (Anonymous, 2009).

A final goal of the HD is to achieve a favourable conservation status for all enlisted habitats and species in the European territory (Article 2 of the HD). The term 'favourable conservation status' is defined in the HD (see also EC 2005, 2006), but has many interpretations (Cantarello and Newton, 2008; Mehtälä and Vuorisalo, 2007; Nielsen et al., 2007).

The assessment of conservation status of habitats and species is a central activity in achieving the final goal of $\mathrm{HD}$. The assessment of conservation status, made by the European Topic Centre on Biological Diversity (ETC/BD), followed the definition given in the HD and was based on four groups of parameters, mentioned in given definition. The HD define conservation status as all the factors that influence habitats or species that may have long-term affect on range, habitat area, population structure and function and their future prospects. Four classes of conservation status were used in the Member State assessments: "favourable", "unfavourable-inadequate", "unfavourable-bad" and "unknown". In 2007, European Union Member States reported on the conservation status of community interest habitats and species for the period 2001-2006. EU analysis, at biogeographical level, shows that only $17 \%$ of both habitats and species assessments were deemed favourable (EEA, 2006).

The implementation of European Union biodiversity legislation in Romania through Nature 2000 Network came in force with OUG 57 of 2007 that transposed into Romanian legislation the Habitats Directive and Birds Directive. After that, the Romanian PAs increased from $4.1 \%$ prior to 1989 to $19.29 \%$ of the national territory due to creation of 27 National and Natural Parks, and recently 382 protected areas as part of the pan-European Natura 2000 network (Iojă et al., 2010). At the next report on the conservation status of habitats and species, to be held in 2013, Romania will take part, which initiated development of the monitoring activities described in this paper. 
The Romanian Nature 2000 Network with relevance on the ichthyofauna is represented by 81 SCIs from a total of 273 SCIs (Curtean-Bănăduc and Florescu, 2007; Florea, 2011). Protected Romanian fish species in the normative acts of the Nature 2000 Network are represented by 27 fish species. The number of community interest fish species presented in one Romanian SCI varies quite widely from one species to a maximum of 16 species per SCI. Of the 27 community interest fish species presented in the 81's SCIs, four fish species (Cottus gobio, Barbus petenyi, Sabanejewia aurata, Cobittis taenia) have a large spreading area, nine species (Romanichthys valsanicola, Eudontomyzon vladykovi, Rutilus pigus, Cobitis elongata, Leuciscus souffia, Eudontomyzon mariae, Alosa caspia, Hucho hucho, Umbra krameri) have a small spreading area, being very rare (Bănărescu and Bănăduc, 2007; Florea, 2011).

In the investigation PAs, included in the Romanian Nature 2000 Network, were named three community interest fish species: Gobio uranoscopus frici Vladykov, 1925 (Danubian longbarbel gudgeon), Barbus petenyi Heckel, 1852 (Danubian rheophilic barb) and Cottus gobio Linné, 1758 (bullhead). In the fishing activities during the spring and summer of 2010 we found two of them, Barbus petenyi and Cottus gobio.

The goal of this study is to evaluate the conservation status of the community interest fish species Cottus gobio and Barbus petenyi from PAs ROSCI0229 Siriu. The research objectives are: (1) to document the biology and the ecology of Cottus gobio and Barbus petenyi; (2) to analyze the distribution of Cottus gobio and Barbus petenyi inside Romania's Natura 2000 net; (3) to analyze the ichthyofauna characteristics of Buzău River and ROSCI0229 Siriu; (4) to document the conservation status and future prospects for species.

\section{The biology and ecology of Cottus gobio and Barbus petenyi}

In Europe the genus Barbus includes 34 species (Fauna Europaea, 2011), but in Romania the genus Barbus includes only four species: Barbus barbus (Linnaeus, 1758), Barbus petenyi Heckel, 1852, Barbus balcanicus Kotlik, Tsigenopoulous, Rab and Berrebi, 2002 and Barbus carpathicus Kotlik, Tsigenopoulous, Rdb and Berrebi, 2002 (Nalbant, 2003). Beside the common barb (Barbus barbus), in the Romanian rivers there are three so-called spotted barb, which characterizes itself by its preference for the colder and more rapid flowing mountain waters. The species Barbus balcanicus is present in Banat and in Jiu River basin and the species Barbus petenyi, in the basins of the rivers Mureş, Argeş, Vedea and Ialomița. In the basin of the Olt River both of them occur (Iftime, 2004). The species Barbus carpathicus is present only in Someş basin, a left tributary of the river Tisa (Nalbant, 2003).

The identification of Barbus petenyi must made according to the following morphological criteria: pectorals without spots; dorsal and caudal with small spots, generally randomly disposed; pair one of barbels is relatively long; snout is relatively pointed (Kotlik et al., 2002), simple radius of the dorsal fin is thin and flexible; the insertion of the ventral fins is behind the dorsal fin insertion; the anal fin is long, sometimes reaching the base of the caudal fin; there are dark spots on its back (Bănărescu, 1964; 1968). The Barbus petenyi is a mediumsized fish growing to 100-170 mm long; in the river network from PAs ROSCI0229 Siriu it had a total length between 37 and $146 \mathrm{~mm}$.

This fish prefers rivers and streams in mountainous and hilly areas, with stony riverbeds, clear and well oxygenated water and a fast-flowing current. It is benthopelagic, and feeds on small invertebrates. It shows preference for strong current and rocky bottom, in its downstream area the Barbus petenyi lives together with Gobio uranoscopus. It is strictly sedentary not doing any migration. It is also a species sensitive to pollution and can easily make hybrid species with B. barbus and B. haasi (Bănărescu, 1964). 
While still common in suitable habitats, the decline of its population is suspected and expected to continue gradually due to on-going economic development. Its distribution in Romania is relatively large, but rather fragmented, though in recent decades it has been expanding. In Romania it can be considered to have low vulnerability. The species is included in the IUCN Red List, Bern Convention, Habitats Directive and protected by Law 462/2001.

In Europe the genus Cottus include seven species (Fauna Europaea, 2011), but in Romania the genus Cottus include only one species Cottus gobio Linnaeus, 1758 (Nalbant, 2003). The bullhead is a small almost cylindrical fish, usually measuring $10 \mathrm{~cm}$, in rare cases reaching $12-13 \mathrm{~cm}$ total length. The head is relatively large (it represents $26-33 \%$ of the total length). The side of the head is armed with spine below the eye, and the preopercula and opercula bones are elongated to form a spine. The lateral line of the body is complete. In Central Europe morphological differences were established between populations from various drainage basins (Riffel at al., 1998). In the Siriu River network the bullhead total length are between seven and $13.5 \mathrm{~cm}$.

The bullhead is a freshwater fish that occurs in cold, clear and fast-flowing shallow water of small stream to medium-sized rivers as well as on gravel or rocky shores of cold lakes (Bănărescu, 1964). Bullhead is a solitary bottom-dwelling fish, each individual defending a territory. Adults do not move between the different stretches of river, but larvae can be passively dispersed downstream after hatching and juveniles actively "explore" neighboring areas before choosing a territory (Chaumota et al., 2006). It feeds mainly on insect larvae, nymphs and other invertebrates, sometimes small fish. The first reproduction occurs when adults are two-years-old or later, length at first maturity being 4.7 to $5 \mathrm{~cm}$. The laying of eggs is in late March-April, after that the male guard the eggs for one month. Larvae become juveniles in fall. Juveniles establish their territory during the first winter of their life.

Investigations linking fish ecology, flow, and physical habitat variability suggest that mesohabitat size, persistence and arrangement may influence fish distribution (Pont et al., 2005; Gosselin et al., 2010). Adults appeared to prefer higher water velocities and coarser substrate and juveniles preferred deeper water and coarser substrate in winter, whereas in summer they appeared to use shallower water (Seeuws et al., 2005). The estimation of the population dynamics was accomplished by using the genetic approach (microsatellite polymorphism) (Knaepkensa et al., 2004; Haenfling et al., 2006), direct field observations (Vlach et al., 2005), or mathematical modeling (Legalle et al., 2005; Chaumota et al., 2006; Charles et al., 2008). There are relatively many multi-scale studies of factors influencing a bullhead distribution allowing integration of patterns observed at different scales and enhancing our understanding of interactions between animals and their environment.

Freshwater fish populations have significantly been reduced and altered due to direct and indirect human activities (Cowx and Welcomme, 1998). Nevertheless, in recent decades, Cottus gobio has suffered a considerable decline in Switzerland, Germany, Flanders (Utzinger et al., 1998), and Austria (Fischer and Kummer, 2000). In the latter by human activities such as pollution. Anthropogenic habitat destruction has modified the natural riverine habitat of this species and consequently had a large impact on the size, range and viability of the local bullhead populations (Utzinger et al., 1998; Hanfling and Brandl, 1998; Hanfling and Weetman, 2006; Knaepkens et al., 2002a, b). Consequently, the species is regarded as highly vulnerable and is fully protected by law in Europe Union (Vandelannoote et al., 1998). In Romania it has a relatively wide range, but due to human impact its range has reduced somewhat. In Romania this species has low vulnerability. It is included in the Bern Convention, Habitats Directive and protected by Law 462/2001. 
The distribution of Cottus gobio and Barbus petenyi inside Romania's Natura 2000 Network

From 2007, the total surface of Natura 2000 Network in România represented a significant part of the country's surface. There are 273 SCIs, representing $13.21 \%$ of the country surface and 108 SPAs, representing $11.89 \%$ of the country surface (MEF/NAE, 2009). From these 273 SCIs only 81 SCIs have fish species which must be protected under the Order 57/2007, Annex 3 - "Species of plants and animals whose conservation requires the designation of SCIs". List of fish species that are found in SCIs, reported in Romania until 2007 (OM. 1964/2007), consist of 26 fish species (Florea, 2010).

Romania possesses five of the ten biogeographic regions officially recognized by the European Union (alpine, continental, panonic, pontic, and steppe), making it one of the most biogeographically diverse country of the EU. The distribution analysis of all 38 SCIs where Barbus petenyi was found and of all 39 SCIs where Cottus gobio was found, in terms of their belonging to the five major biogeographic regions shows us the following (Fig. 1):

> alpine bioregion has 19 SCIs with Barbus petenyi and 24 SCIs with Cottus gobio;

$>$ continental bioregion has 16 SCIs with Barbus petenyi and 15 SCIs with Cottus gobio;

$>$ panonic bioregion has two SCIs with Barbus petenyi and no SCIs with Cottus gobio;

$>$ steppe bioregion has one SCIs with Barbus petenyi and no SCIs with Cottus gobio;

$>$ pontic bioregion has no SCIs with Barbus petenyi and no SCIs with Cottus gobio.

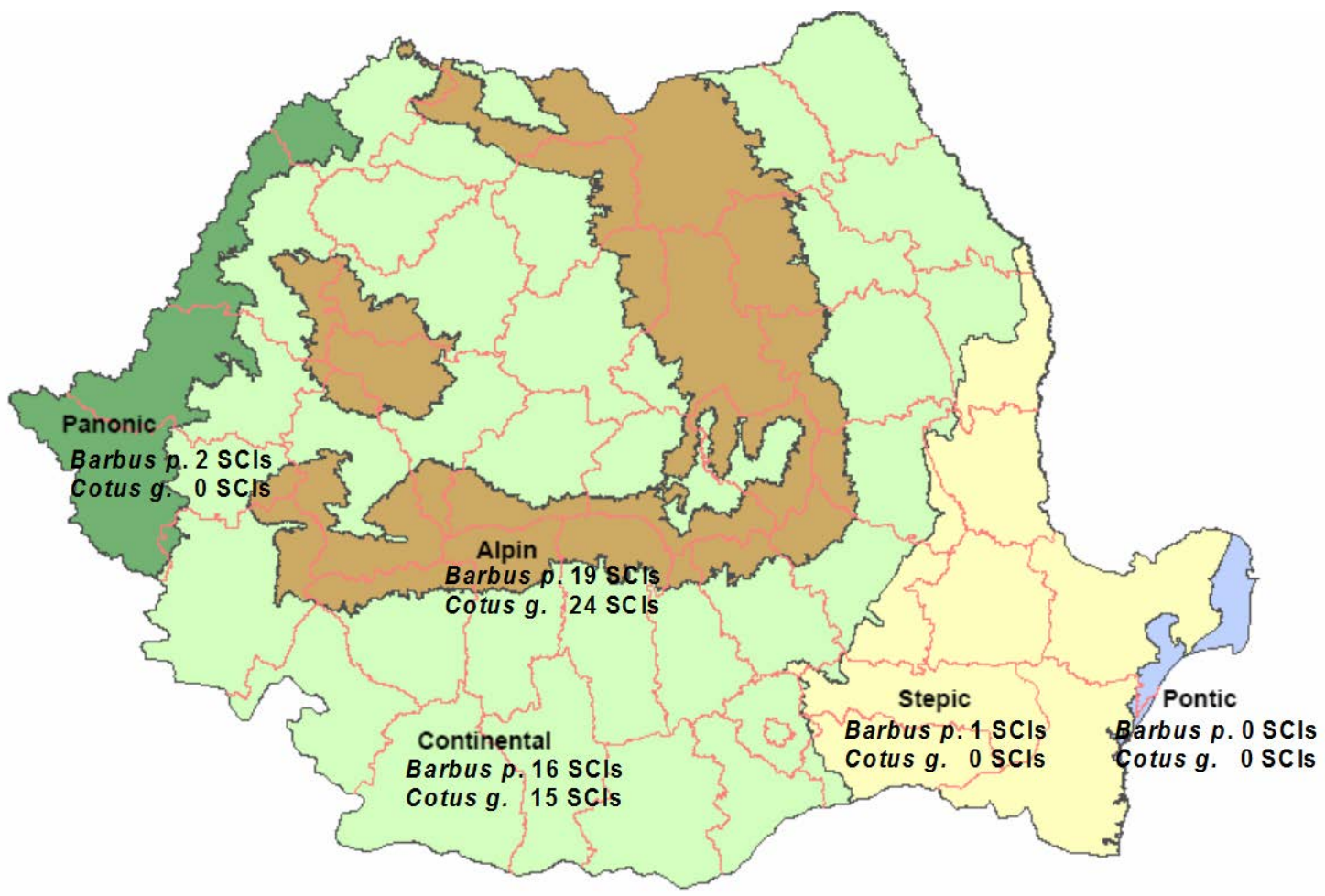

Figure 1: The distribution of SCI-s with Barbus petenyi and Cottus gobio in biogeographic regions of Romania. 
The total number of SCIs where both species are present is 48, of which 29 SCIs have both species, 10 SCIs have only Cottus gobio and nine SCIs have only Barbus petenyi. The analysis of the protected fish distribution in national Natura 2000 Network show that Cottus gobio species is present only in alpine and continental bioregion and Barbus petenyi species is present in those regions and also in panonic and steppe bioregion. The medium altitude of SCIs varies significantly for the SCIs with Cottus gobio species from the SCIs with Barbus petenyi species (Fig. 2). The map of distribution of these species (Fig. 3) was made using the official maps of occurrence of these two species, provided by the Order of Minister of Environment and Sustainable Development no. 1964/2007 (MESD, 2007).

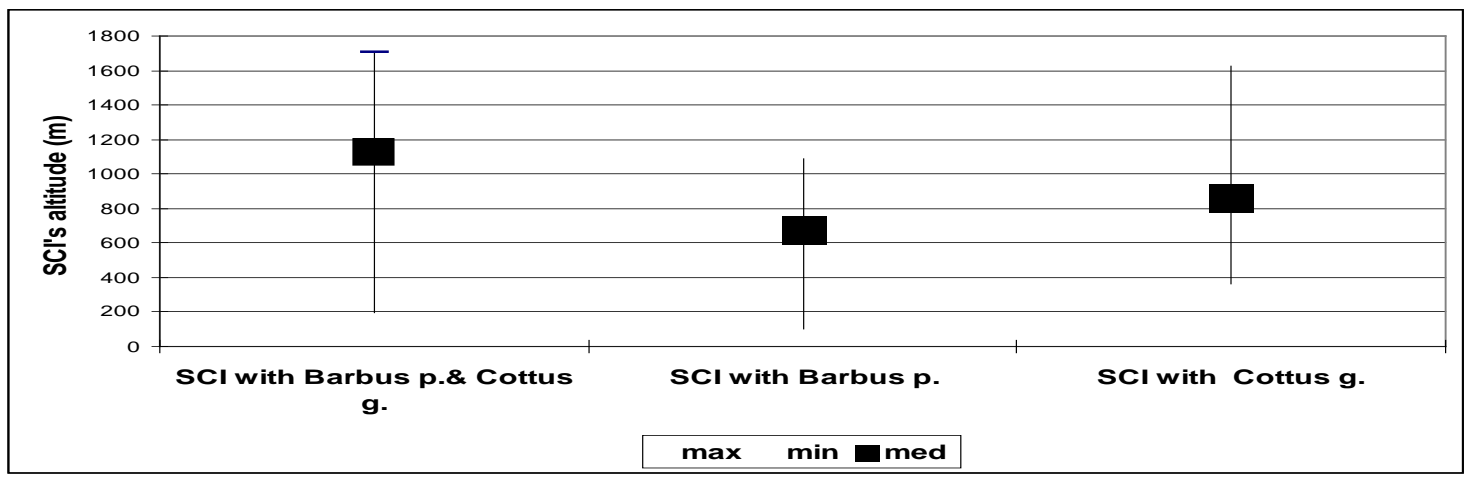

Figure 2: The variation of SCIs medium altitude for SCIs with B. petenyi, SCIs with C. gobio and SCIs with B. petenyi and C. gobio.

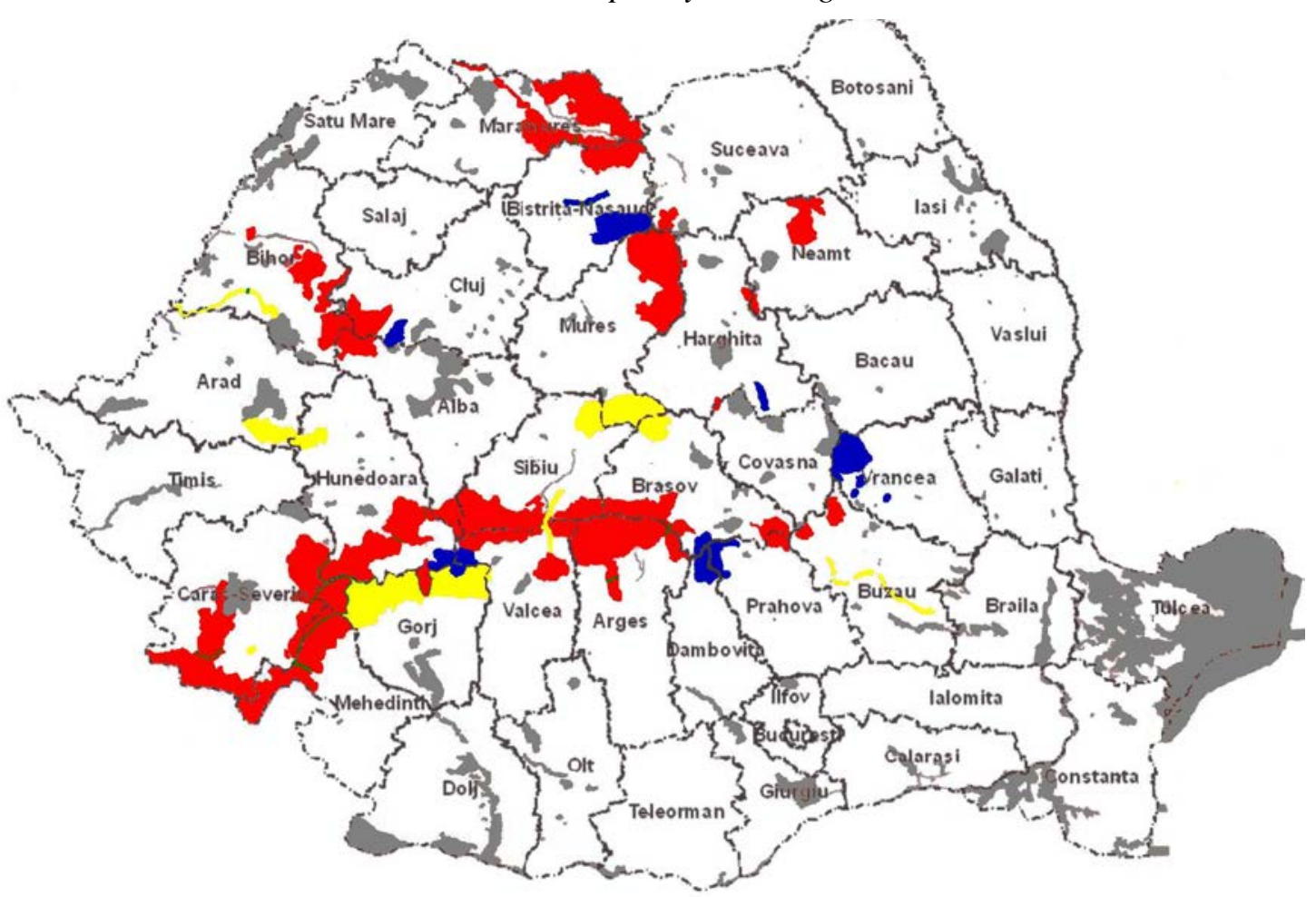

Figure 3: The range of B. petenyi and C. gobio inside Romania's SCIs network Red - 29 SCIs with C. gobio and B. petenyi Blue - 10 SCIs with C. gobio Yellow - nine SCIs with B. petenyi. 


\section{The ichthyofauna characteristics of Buzău River and ROSCI0229 Siriu}

The past of Buzău River ichthyofauna is presented in the study "R. P. R. Fauna, Pisces: Osteichthyes” by the Romanian ichthyologist Bănărescu P. M., citing for the Buzău River 22 species of fish belonging to six families. The ichthyofauna of the rivers ecosystems from the Buzău hydrographic basin, from its source to its mouth, due to the presence of a large variety of landforms, has been divided into five fish zones (Bănărescu, 1964).

In the mountains: the trout zone (Salmo fario), the grayling zone (Thymallus thymallus) and the Mediterranean barbel area (Barbus petenyi).

In the hills: the sneep zone (Chondostroma nasus), the barbel zone (Barbus barbus);

In the plains: the carp zone (Cyprinus carpio).

Both in the mountains and in the hills and plains, within about 30 years, from 1964 to 1998, major changes in fisheries are highlighted (Figs. 4 and 5). In both periods the trout area is well represented. The mountain area of Buzău offered exceptional conditions for the trout (Salmo trutta fario) with whom in the past there has also been observed the minnow (Phoxinus phoxinus), the bullhead (Cottus gobio), the loach (Orthrias barbatulus), the bleak (Alburnoides bipunctatus). All these species have been reported in the present too. In contrast, in the 60s the grayling population was well represented on the Buzău River, which was not confirmed by the recent studies (Dimulescu, 1998). In the grayling and the barbel area, the grayling (Thymallus thymallus) occupies well individualized and surface limited areas, but the barbel (Barbus petenyi) was encountered on more extensive areas, also in the mountains, and downstream, with the chub (Squalius cephalus) and the common dace (Leuciscus leuciscus) (Bănărescu, 1964) (Fig. 4).

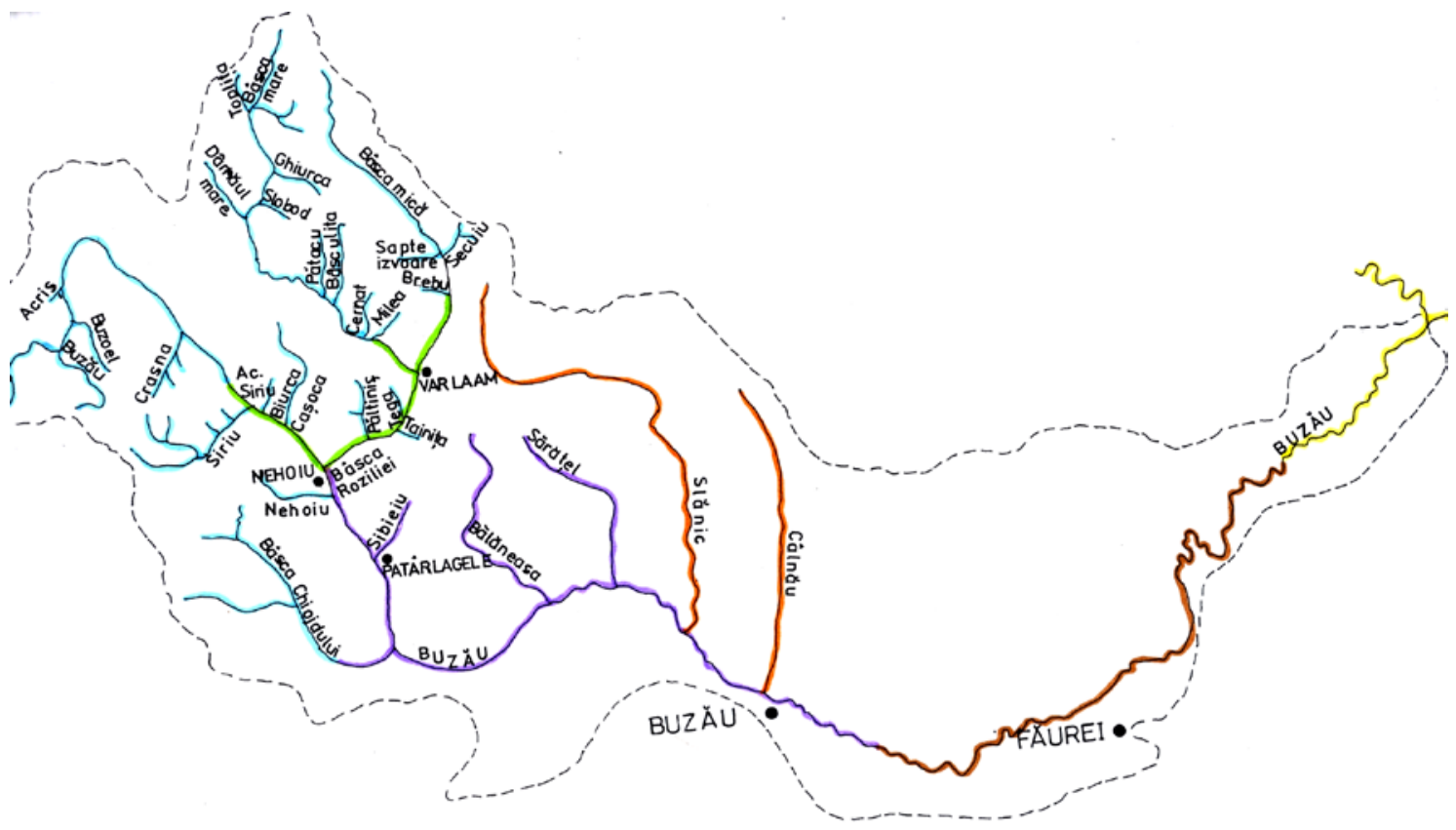

Figure 4: Fish zoning of Buzău's hydrographic basin in 1964, after Bănărescu P. M.; blue - the trout zone; green - the grayling and the barbel zone; purple - thesneep zone; brown - the barbel zone; yellow - the carp zone; orange - zone without fish fauna. 
In 1994, the construction of the Siriu Dam was done. The dam is made of rock, tailings and clay core. The purposes of the dam were to supply industrial water supply, to irrigate the agricultural land and, production of electricity by building Nehoiașu hydroelectric power station. The dam also serves as protection against flood. Siriu Lake was formed as a result of daming the Buzău River in the Siriu Village; it has an area of five $\mathrm{km}^{2}$ and an average depth of $45 \mathrm{~m}$ (www.rowater.ro/daBuzău/). After the construction of the Siriu Lake, it was noticed that the grayling zone shrank drastically due to the change of the downstream flow regime and also due to the mining works of the mineral aggregates in the upstream riverbed. In addition, due to the invasion of the sneep populations, the grayling populations have been pushed upstream, and their area was limited to $10 \mathrm{~km}$ on the Buzău River, upstream of the confluence with the Crasna River and to 20 km on other left tributary of Buzău (Dimulescu, 1998) (Fig. 5).

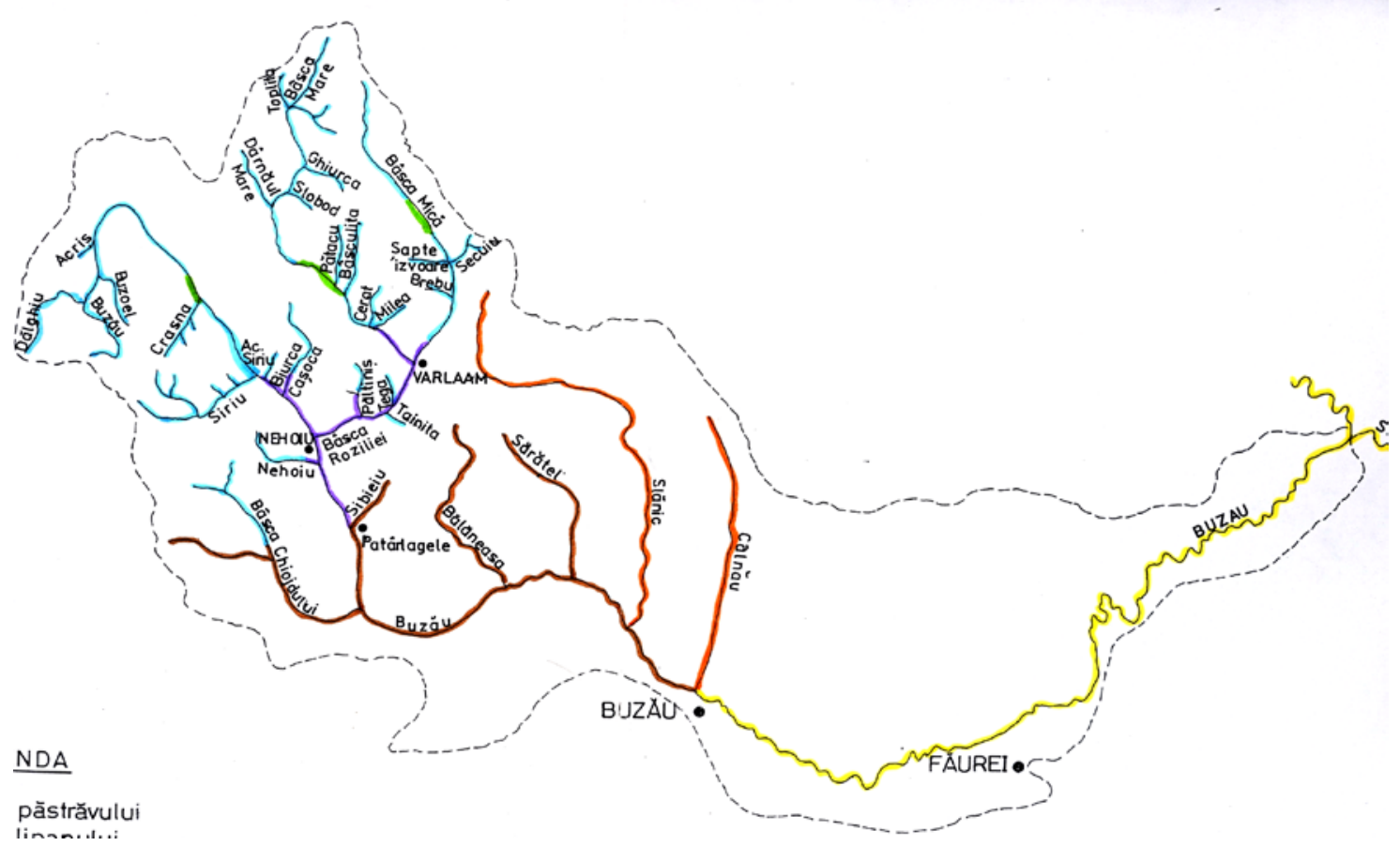

Figure 5: Fish zoning of Buzău’s hydrographic basin in 1998 after Dimulescu N.;

blue - the trout zone; green - the grayling and barbel zone; purple - the sneep zone; brown - the barbel zone, yellow - the carp zone; orange - zone without fish fauna.

In the present the ichthyofauna of ROSCI0229 Siriu is composed of 10 species of fish caught in June and September 2010, the scientific name being the one that has been recently updated (Nalbant, 2003) (Tab. 1).

The lack of the grayling catch in 2010 confirms the reports from 1998 that pointed to the grayling restriction of the distribution area with about $80 \%$ of the area occupied in 1964 and pushing the distribution areal upstream (Dimulescu, 1998). This shrinkage and fragmentation of the grayling distribution area is due to the Siriu dam lake construction and to the change of the flow regime downstream, the grayling populations advancing upstream of the Siriu dam lake. The presence of the rainbow trout, both in the past and in the present, is totally random, being possible because before 1990 in ROSCI 0229 Siriu this new species were populated, but that effort proved totally inefficient. 
Table 1: The ROSCI0229 list of fish species from past (1998) and present (2010).

\begin{tabular}{|c|l|l|l|l|}
\hline \multirow{2}{*}{} & \multicolumn{2}{|c|}{ List of fish species } & \multicolumn{2}{c|}{ Common name } \\
\cline { 2 - 5 } & Past (1998) & Present (2010) & Romanian & English \\
\hline 1. & Barbus petenyi & Barbus petenyi & moioagă & spotted barbel \\
\hline 2. & Cottus gobio & Cottus gobio & zglăvoacă & bullhead \\
\hline 3. & Squalius cephalus & Squalius cephalus & clean & chub \\
\hline 4. & Alburnoides bipunctatus & Alburnoides bipunctatus & beldiță & sperlin \\
\hline 5. & Alburnus alburnus & Alburnus alburnus & obleţ & bleak \\
\hline 6. & Chondrostoma nasus & Chondrostoma nasus & scobar & mackerell \\
\hline 7. & Salmo fario & Salmo fario & păstrav indigen & river trout \\
\hline 8. & Rhabdofario mykiss & Rhabdofario mykiss & păstrav curcubeu & rainbow trout \\
\hline 9. & Phoxinus phoxinus & Phoxinus phoxinus & boiștean & minnow \\
\hline 10. & Orthrias barbatulus & Orthrias barbatulus & grindel & stone loach \\
\hline 11. & Thymallus thymallus & & lipan & grayling \\
\hline
\end{tabular}

The ichthyofauna of the Buzău River and its tributaries within ROSCI0229 is characteristic for the trout zone. The streams from the Siriu Massive offer exceptional conditions for the growth and the development of the river trout, this fact being noticed within the basic fishing activity from September 2010. Thus, in the Crasna station (45.65301 latitude, 26.00877 longitude, $831 \mathrm{~m}$ altitude, slope $4.5 \%$ ), they caught on an area of 220 square meters a total number of 40 specimens of river trout. From the analysis of the catch (Fig. 6) it is observed a balanced structure of the age groups and a favourable average weight of age groups.

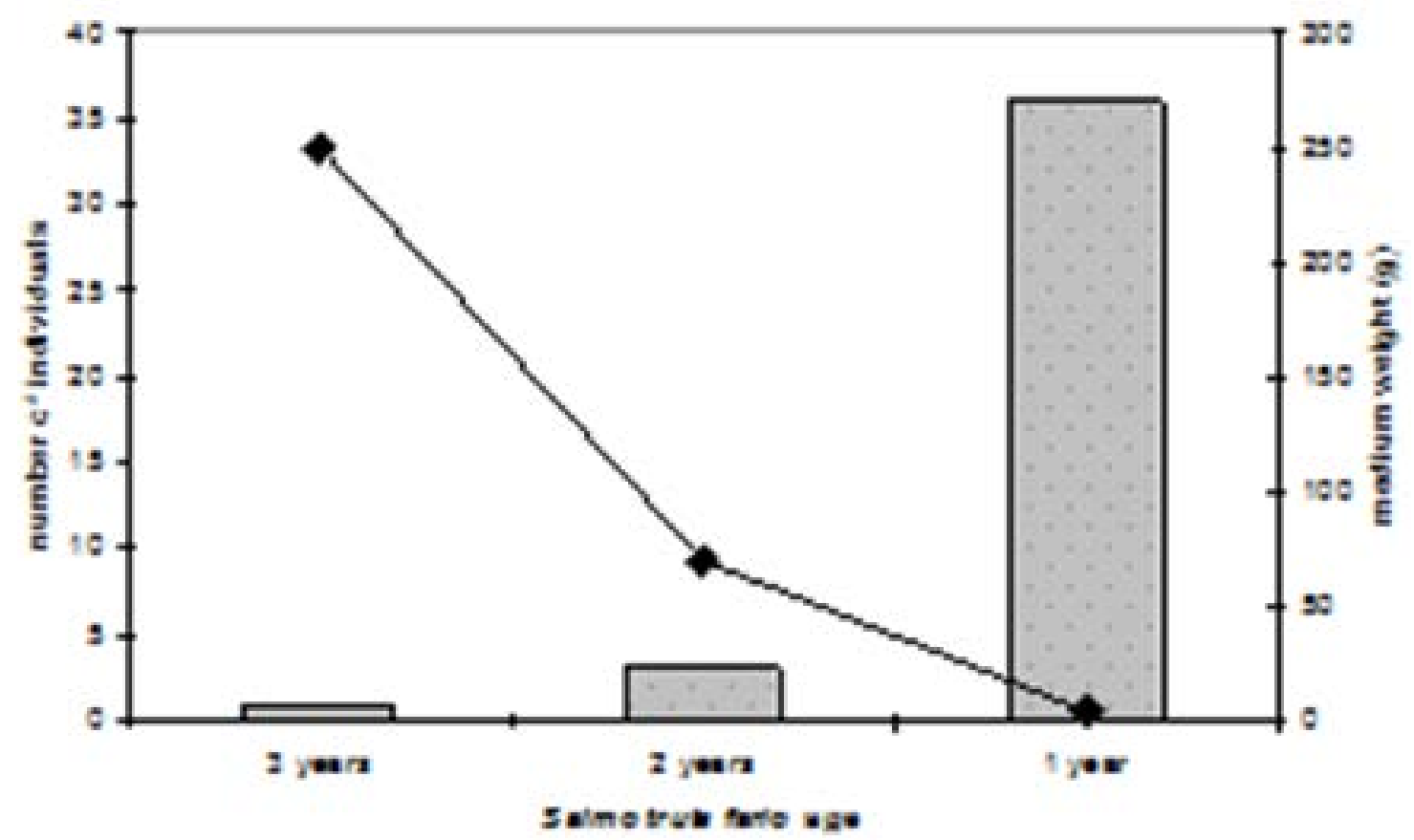

Figure 6: The capture of Salmo fario from Crasna 1 fishing station at 11.09.2010. 


\section{MATERIAL AND METHODS}

The ROSCI0229 Siriu, part of Buzău River basin, is framed as part of ecoregion 10 Carpathian Mountains (Ilieș, 1978) and as part of alpine bioregion, with a total surface of 5.747 ha, has the following geographical coordinates: 4531'28” $\mathrm{N}, 26^{\circ} 9^{\prime} 43^{\prime \prime} \mathrm{E}, 546 \mathrm{~m}$ minimum altitudinal and 1,663 m maximum altitudinal (Fig. 7).

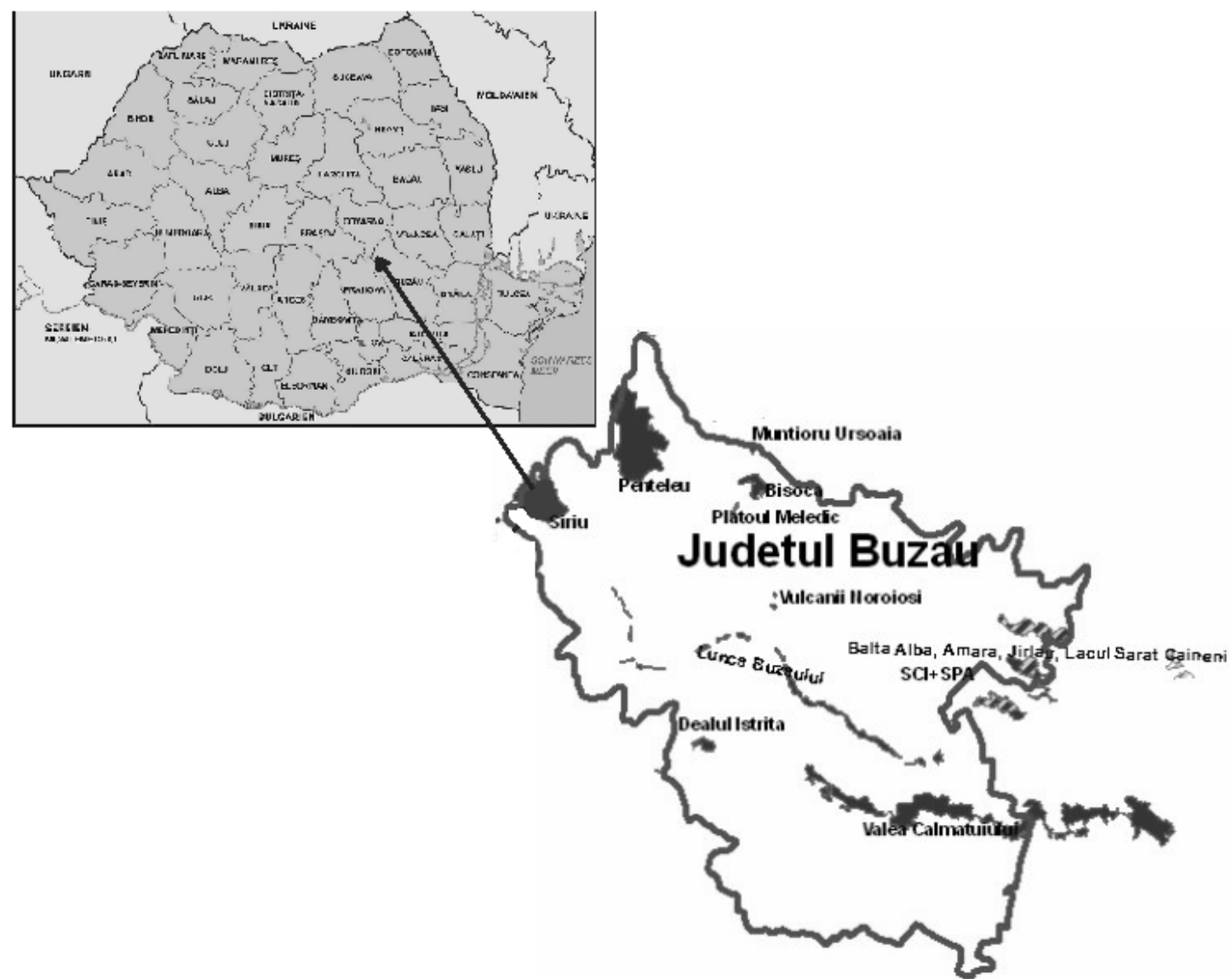

Figure 7: The localization of PAs ROSCI0229 Siriu.

The hydrographic network of PAs ROSCI0229 Siriu, tributary to Buzău River, is a circular network composed by nine streams which descended from the highest peaks, streams that have rather ephemeral flow. In spring (from late April to June) they are more active and formed gradually downstream tumultuous courses carrying large volumes of rock.

We investigated three rivers, Buzău River, Siriu River and Crasna River, which present homogeneous conditions of habitat and which are delimited by confluence (Fig. 8). Investigated rivers were chosen to analyze heterogeneity of environmental conditions of the hydrographic network of PAs ROSCI0229 Siriu. Table 2 reports the main morphological features of these three different rivers according to Management Plan River (NARW, 2009).

The most important parameters which largely influence the habitat conditions from the streams are represented by the slope of the land and the type of the substrate. Of course there are also other environmental factors that influence stream life such as: water chemistry, light, water depth, etc. Minor riverbed morphology is very important and in the case of the fishing stations from ROSCI0229 Siriu this morphology varied within quite wide limits, from waters of two m widths and $20 \mathrm{~cm}$ depths to water up to $120 \mathrm{~m}$ widths and $120 \mathrm{~cm}$ depths (Tab. 2). 


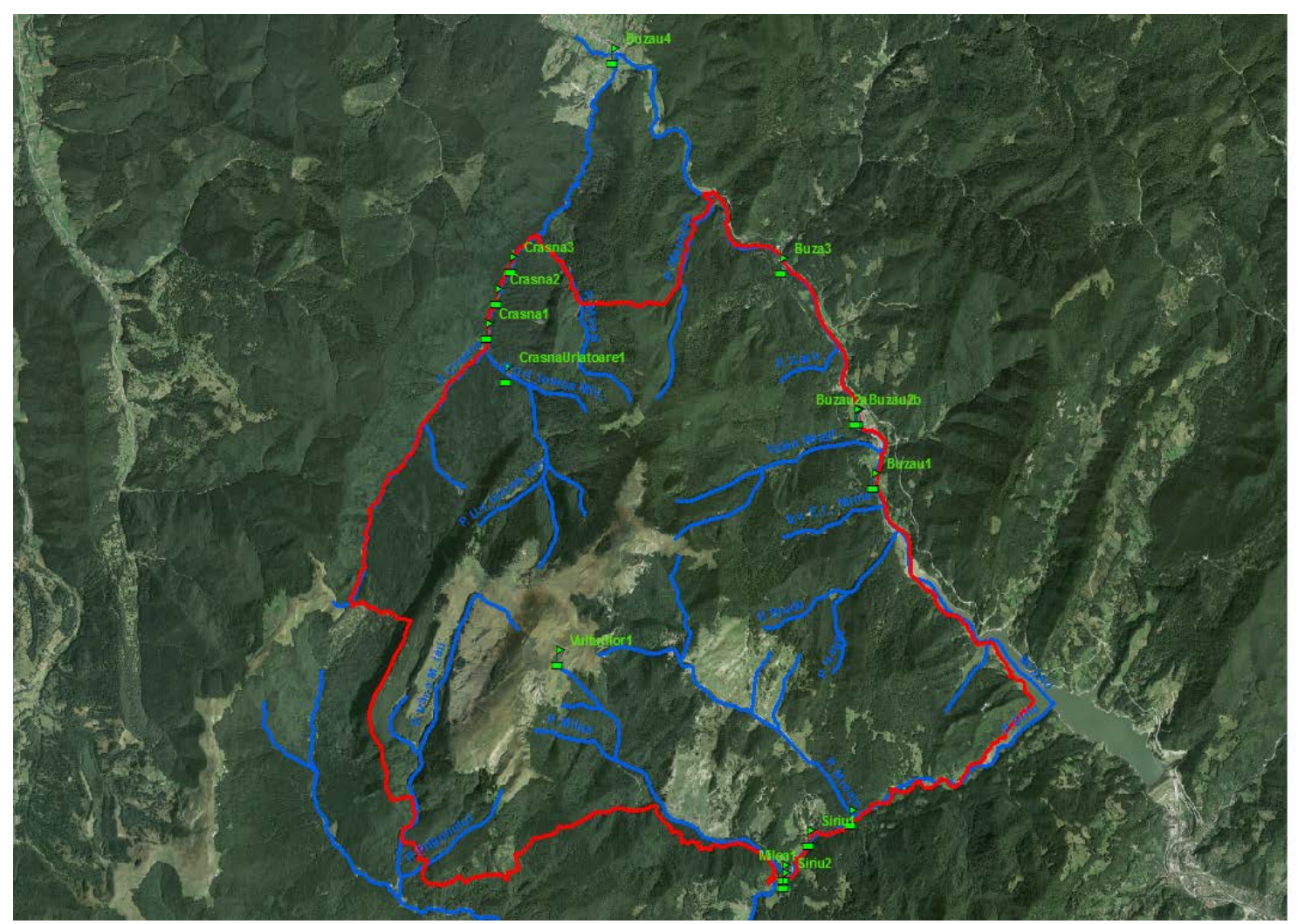

Figure 8: The hydrographic network of PAs ROSCI0229 Siriu and the fishing stations.

Table 2: The morphological features of the investigated river stretches.

\begin{tabular}{|l|c|c|c|}
\hline \multirow{2}{*}{ Features } & \multicolumn{3}{|c|}{ Stretches of river } \\
\cline { 2 - 4 } & Buzău & Siriu & Crasna \\
\hline hydrographic positioning & order three & order two & order one \\
\hline sector slope & $0.82 \%$ & $1.3 \%$ & $5.1 \%$ \\
\hline total length & $60 \mathrm{~km}$ & $30 \mathrm{~km}$ & $20 \mathrm{~km}$ \\
\hline shading & null & less important & important \\
\hline substrate type: & & & \\
\% boulders & 25 & 10 & 50 \\
\% gravel & 50 & 65 & 35 \\
\% sand & 25 & 25 & 15 \\
\hline width & $3-15 \mathrm{~m}$ & $6-8 \mathrm{~m}$ & $2-4 \mathrm{~m}$ \\
\hline depth & $30-120 \mathrm{~cm}$ & $20-50 \mathrm{~cm}$ & $20-40 \mathrm{~cm}$ \\
\hline \% current area & 80 & 100 & 100 \\
\hline \% shallow area & 20 & - & - \\
\hline \% monitored sector & 25 & 50 & 50 \\
\hline no. fishing stations & 5 & 2 & 3 \\
\hline
\end{tabular}

A total of 14 fishing activities were made in 10 fishing stations in the summer of 2010, in June and September. The fishing stations codes and their localization are: for Buzău River B1, B2a, B2b, B3, B4; for Siriu River: S1, S2; for Crasna River: C1, C2 C3. 
The fishing stations were described by hydrographical characteristics (Fig. 9) and hydrological characteristics (Fig. 10). The geographical coordinates of the fishing stations for the rivers have been set by using the GPS that shows the latitude, the longitude and the altitude with an accuracy of $0.8 \mathrm{~m}$. The determination of the land slope was done indirectly through calculation. The width and the depth of the water were measured directly on the field using a ruler and water velocity was measured directly using a flow meter.

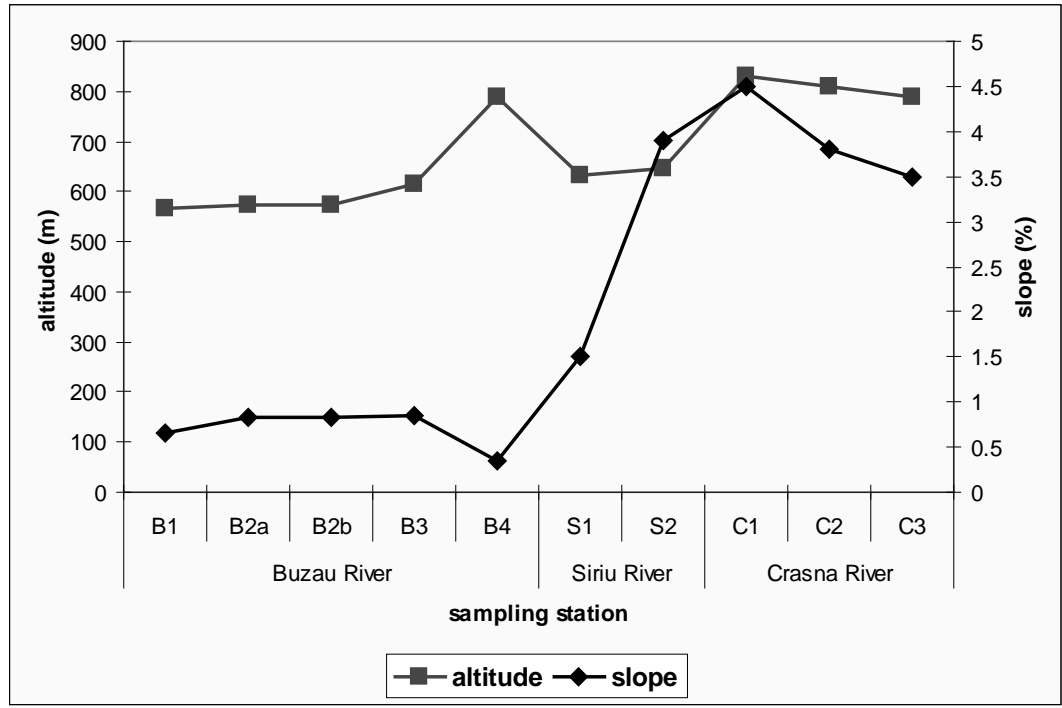

Figure 9: The altitude and the ground slope in the fishing stations.

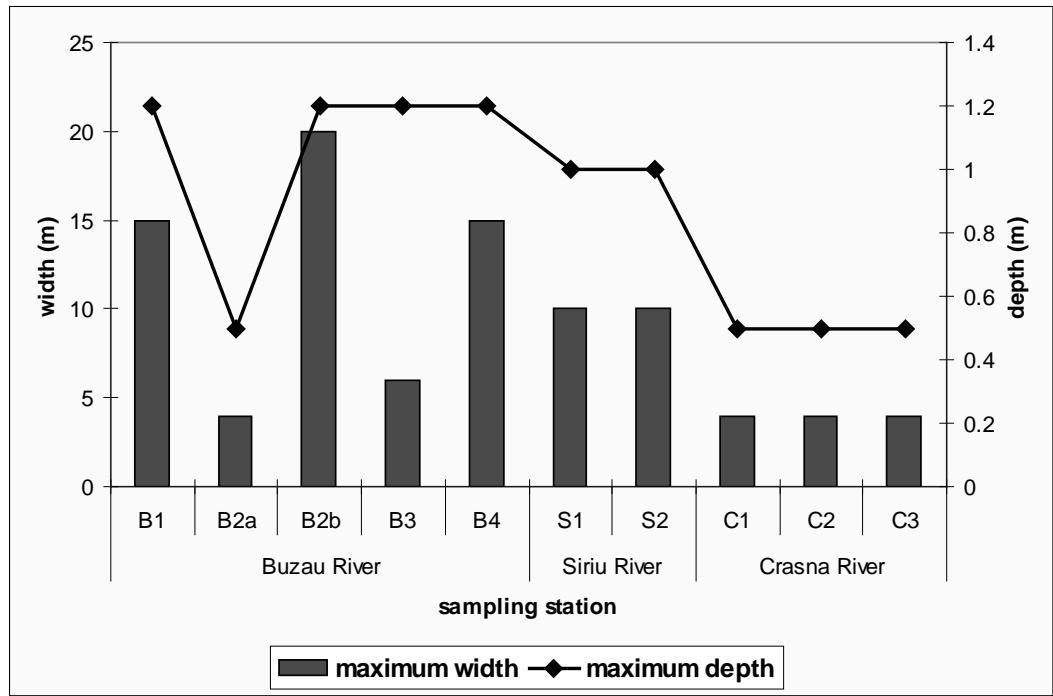

Figure 10: The river width and the depth in the fishing stations.

The sampling of fish was made by electrofishing, according to standard operational procedure (Davideanu, 2005). A portable fishing device, type ELT62II was used. Fishing was done on foot, zigzag from one bank to another over the entire stream, recording the length and the fished area (Fig. 11). Electrofishing was carried out in a river stretch along a distance between a minimum of $80 \mathrm{~m}$ and a maximum of $165 \mathrm{~m}$, with a fishing surface between a minimum of $557 \mathrm{~m}^{2}$ and a maximum of $1,750 \mathrm{~m}^{2}$ (Fig. 12). 
Species identification was carried out according to several morphological characteristics, using determination keys for every systematical unit and species description from the literature (Bănărescu, 1964). The recorded catch for each station is shown in figure 6. On the whole, in the 14 fishing sectors, a total number of 149 fish were collected, of which 49 were Barbus meridionalis petenyi and 37 were Cottus gobio. For each individual was made the most important somatic measurements, total body length (Tl) and body weight (W). For the body length we use a caliper and for the body weight we use an electronic balance.

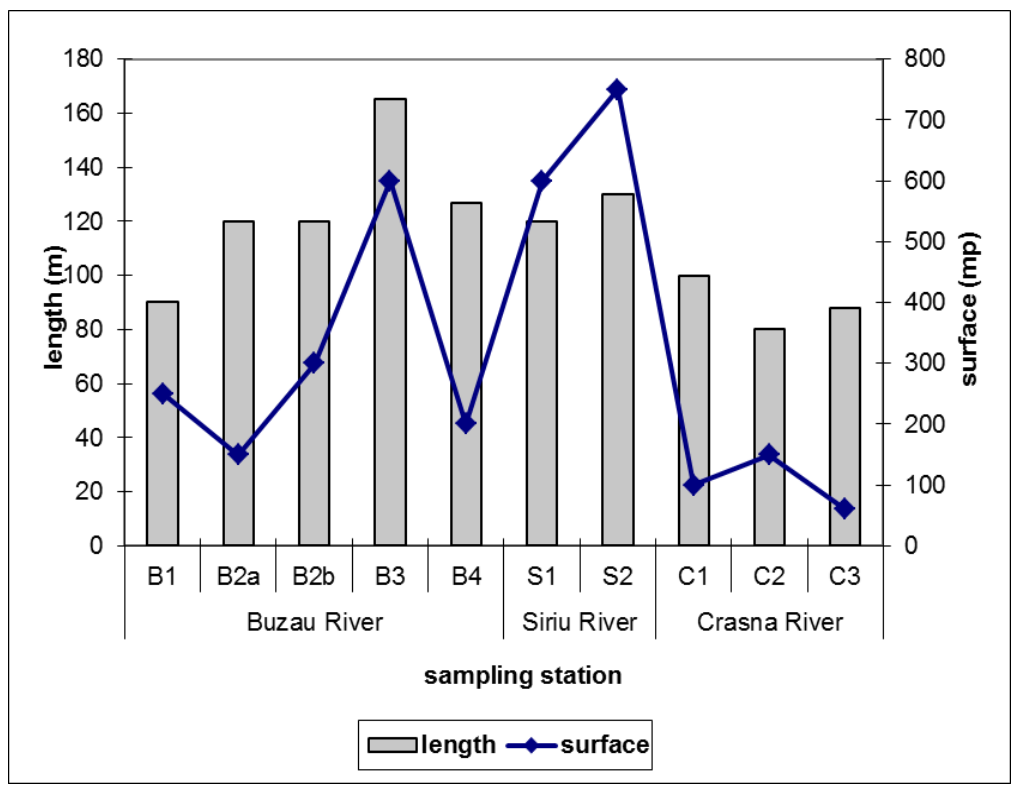

Figure 11: The length and the surface of fishing stations.

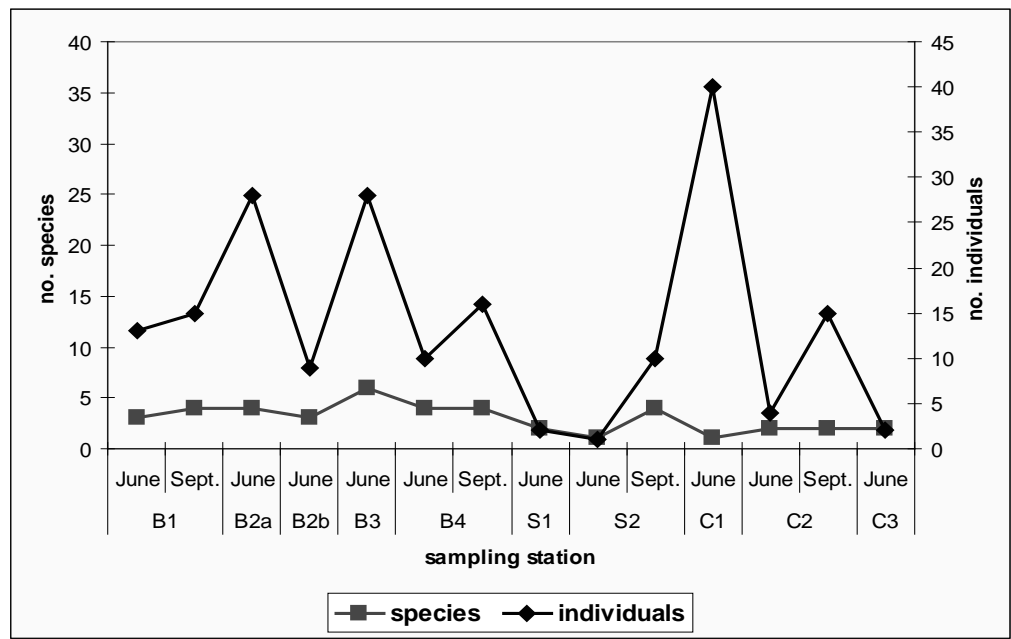

Figure 12: The number of the species and individuals caught in the fishing stations.

\section{RESULTS AND DISCUSSION}

The purpose of the fishing activity was to assess the conservation status of these two species of community interest from ROSCI 0229. The results of the fishing activity are listed in tables 3 and 4. 
Table 3. Fish capture from PAs ROSCI0229 Siriu in 2010.

\begin{tabular}{|c|c|c|c|c|c|}
\hline Station & Data & \multicolumn{2}{|c|}{ Total fish capture } & \multirow{2}{*}{$\begin{array}{c}\text { Barbus } m . \\
\text { no. indiv } \\
(\text { An\%) }\end{array}$} & $\begin{array}{c}\text { Cottus g. } \\
\text { no. indiv } \\
(\text { An\%) }\end{array}$ \\
\cline { 3 - 4 } & $\begin{array}{c}\text { no. species/ } \\
\text { station }\end{array}$ & $\begin{array}{c}\text { no. ind./ } \\
\text { station }\end{array}$ & $9(69 \%)$ & $0(0 \%)$ \\
\hline \multirow{2}{*}{ B1 } & 05.06 & 3 & 13 & $9(27 \%)$ & $5(33 \%)$ \\
\cline { 2 - 4 } & 10.09 & 4 & 15 & $4(75 \%)$ & $5(18 \%)$ \\
\hline B2a & 05.06 & 4 & 28 & 21 & $0(0 \%)$ \\
\hline B2b & 05.06 & 3 & 9 & $5(55 \%)$ & $7(25 \%)$ \\
\hline B3 & 05.06 & 6 & 28 & $4(14 \%)$ & $3(30 \%)$ \\
\hline \multirow{2}{*}{ B4 } & 05.06 & 4 & 10 & $1(10 \%)$ & $0(0 \%)$ \\
\cline { 2 - 4 } & 10.09 & 4 & 16 & $3(19 \%)$ & $1(50 \%)$ \\
\hline S1 & 05.0 & 2 & 2 & $0(0 \%)$ & $1(100 \%)$ \\
\hline \multirow{2}{*}{ S2 } & 07.06 & 1 & 1 & $0(0 \%)$ & $2(20 \%)$ \\
\cline { 2 - 4 } & 11.09 & 4 & 10 & $2(20 \%)$ & $0(0 \%)$ \\
\hline C1 & 05.06 & 1 & 40 & $0(0 \%)$ & $3(75 \%)$ \\
\hline \multirow{2}{*}{ C2 } & 07.06 & 2 & 4 & $0(0 \%)$ & $9(60 \%)$ \\
\cline { 2 - 4 } & 11.09 & 2 & 15 & $0(0 \%)$ & $1(50 \%)$ \\
\hline C3 & 05.06 & 2 & 2 & $0(0 \%)$ & 37 ind. (19\%) \\
\hline Total & & 10 sp. & 193 ind. & 49 ind. $(25 \%)$ & \\
\hline
\end{tabular}

Table 4: Unitary fish capture (ind./100 $\mathrm{m}^{2}$ and g/100 p) in ROSCI0229 Siriu in 2010.

\begin{tabular}{|c|c|c|c|c|c|c|}
\hline \multirow[t]{2}{*}{ Station } & \multicolumn{2}{|c|}{$\begin{array}{c}\text { Unitary fish capture } \\
\text { per station }\end{array}$} & \multicolumn{2}{|c|}{$\begin{array}{l}\text { Unitary fish capture } \\
\text { per Barbus } m \text {. }\end{array}$} & \multicolumn{2}{|c|}{$\begin{array}{l}\text { Unitary fish capture } \\
\text { per Cottus g. }\end{array}$} \\
\hline & ind. $/ 100 \mathrm{~m}^{2}$ & $\mathrm{~g} / 100 \mathrm{~m}^{2}$ & ind. $/ 100 \mathrm{~m}^{2}$ & $\mathrm{~g} / 100 \mathrm{~m}^{2}$ & ind. $/ 100 \mathrm{~m}^{2}$ & $\mathrm{~g} / 100 \mathrm{~m}^{2}$ \\
\hline \multirow{2}{*}{ B1 } & & & 3.6 & 284 & 0 & 0 \\
\hline & 6.0 & 184 & 1.6 & 56 & 2 & 24 \\
\hline B2a & 18.0 & 1782.66 & 14 & 1550.66 & 3.33 & 86.66 \\
\hline B2b & 3.0 & 480 & 0 & 130 & 0 & 0 \\
\hline B3 & 4.6 & 417.5 & 1.66 & 70 & 2.33 & 85 \\
\hline \multirow{2}{*}{ B4 } & 5.0 & 585 & 0.66 & 35 & 0.5 & 120 \\
\hline & 8.0 & 568 & 0.5 & 51.5 & 0 & 0 \\
\hline S1 & 3.0 & 8.33 & 1.5 & 15 & 0.5 & 11.66 \\
\hline \multirow{2}{*}{ S2 } & 1 & 1.33 & 0 & 0 & 0.16 & 1.33 \\
\hline & 10 & 28 & 0 & 0 & 0.26 & 5.33 \\
\hline C1 & 40 & 573 & 0.26 & 0 & 0 & 0 \\
\hline \multirow{2}{*}{$\mathrm{C} 2$} & 2.6 & 120 & 0 & 0 & 3 & 40 \\
\hline & 10 & 466.66 & 0 & 0 & 6 & 33.33 \\
\hline C3 & 3.0 & 233.33 & 0 & 0 & 0.66 & 83.33 \\
\hline
\end{tabular}

In order to establish the population status several biological concepts linked to community dynamics may be use. For example, many studies use two analytical indices: frequency and numerical abundance of species. 
- $\quad$ Frequency $(\mathbf{F} \%)=(\mathrm{p} / \mathrm{P}) \times 100$

$\mathrm{p}=$ number of samples in which the species occurs;

$\mathrm{P}=$ total number of samples.

- The Constant (C) - is expressed in terms of frequency. Depending on the value of the frequency, species belong to the following classes of constant (Varvara et al., 2001):

C1 - accidental species - when the frequency is between 1-25\%;

$\mathrm{C} 2$ - accessories species - when the frequency is between $25.1-50 \%$;

C3 - constant species - when the frequency is between $50.1-75 \%$;

C4 - euconstant species - when the frequency is between $75.1-100 \%$.

- $\quad$ Numerical abundance $(A n \%)=(n / N) \times 100$

$\mathrm{n}=$ number of individuals of a given species from the analyzed sample;

$\mathrm{N}=$ total number of individuals of all species present in the sample.

- Dominance (D):

D1 - below recendent species - when numerical abundance is below $2 \%$;

D2 - recendent species - when numerical abundance is between 1.12.1-5\%;

D3 - below dominant species - when numerical abundance is between

D4 - dominant species - when numerical abundance is between 5.1$10 \%$;

D5 - eudominant species - when numerical abundance is over $10.1 \%$.

- Ecological significance $(W \%)=($ F x An $) / 100$ :

W1 - accidental species - when the ecological significance is below 1.1\%;

W2 - accidental - accompanying species - when the ecological significance is between 1.1-2\%;

W3 - accompanying species - when the ecological significance is between 2.1$5 \%$;

W4 - accompanying - characteristic species - when the ecological significance is between $5.1-10 \%$.

W5 - characteristic species - when the ecological significance is over $10.1 \%$.

The three classes are used for assessing the population status: favorable, medium favorable and unfavorable (Tab. 5). 
Table 5: General evaluation matrix of population status (PS).

\begin{tabular}{|c|c|c|c|c|c|c|c|}
\hline \multicolumn{2}{|c|}{} & \multicolumn{3}{|c|}{ Barbus petenyi } & \multicolumn{3}{c|}{ Cottus gobio } \\
\hline No. & indices & $\begin{array}{c}\text { favorable } \\
\text { "F" }\end{array}$ & $\begin{array}{c}\text { medium } \\
\text { favorable } \\
\text { "MF" }\end{array}$ & $\begin{array}{c}\text { unfavorable } \\
\text { "UF" }\end{array}$ & $\begin{array}{c}\text { favorable } \\
\text { "F" }\end{array}$ & $\begin{array}{c}\text { medium } \\
\text { favorable } \\
\text { "MF" }\end{array}$ & $\begin{array}{c}\text { unfavorable } \\
\text { "UF" }\end{array}$ \\
\hline 1. & $\begin{array}{c}\text { (F) } \\
\text { frequency }\end{array}$ & $\begin{array}{c}50.1 \%- \\
100 \%\end{array}$ & $\begin{array}{c}25.1 \%- \\
50 \%\end{array}$ & $\begin{array}{c}1 \%- \\
25 \%\end{array}$ & $\begin{array}{c}25.1 \%- \\
100 \%\end{array}$ & $\begin{array}{c}1 \%- \\
25 \%\end{array}$ & $0 \%$ \\
\hline 2. & $\begin{array}{c}\text { (An) } \\
\text { numerical } \\
\text { abundance }\end{array}$ & $>10.1 \%$ & $\begin{array}{c}5.1 \%- \\
10 \%\end{array}$ & $<5 \%$ & $>5.1 \%$ & $\begin{array}{c}1 \%- \\
5 \%\end{array}$ & $0 \%$ \\
\hline 3. & $\begin{array}{c}\text { (W) } \\
\text { ecological } \\
\text { significance }\end{array}$ & $>5.1 \%$ & $\begin{array}{c}1.1 \%- \\
5 \%\end{array}$ & $<1.1 \%$ & $>2.1 \%$ & $\begin{array}{c}1.1 \%- \\
2 \%\end{array}$ & $<1.1 \%$ \\
\hline 4. & $\begin{array}{c}\text { Overall } \\
\text { evaluation } \\
\text { of PS }\end{array}$ & All "F" & $\begin{array}{c}\text { One/two } \\
\text { "MF" } \\
\text { but no } \\
\text { "UF" }\end{array}$ & $\begin{array}{c}\text { One or two } \\
\text { "UF" }\end{array}$ & All "F" & $\begin{array}{c}\text { One/two } \\
\text { "MF" } \\
\text { but no } \\
\text { "UF" }\end{array}$ & $\begin{array}{c}\text { One or two } \\
\text { "UF" }\end{array}$ \\
\hline
\end{tabular}

The values of frequency (F\%) and numerical abundance (An\%) (Fig. 13) indicate for the Barbus petenyi a favorable status for Buzău River, medium favorable status for Siriu River and unfavorable status for Crasna River. For Cottus gobio analytical indices (Fig. 14) indicate a favorable status for Siriu and Crasna rivers and medium favorable status for Buzău River.

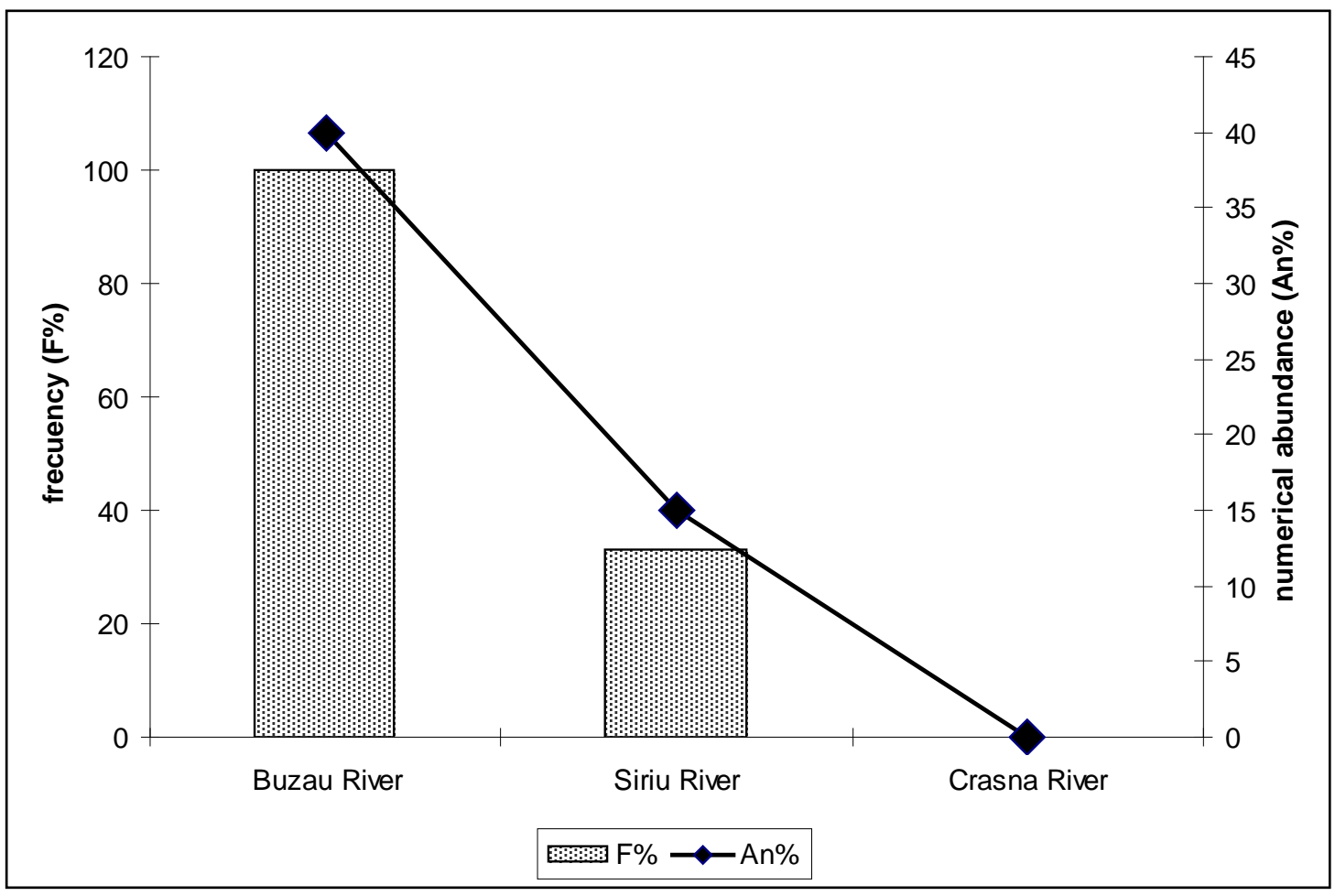

Figure 13: Barbus petenyi frequency (F\%) and numerical abundance (An\%). 


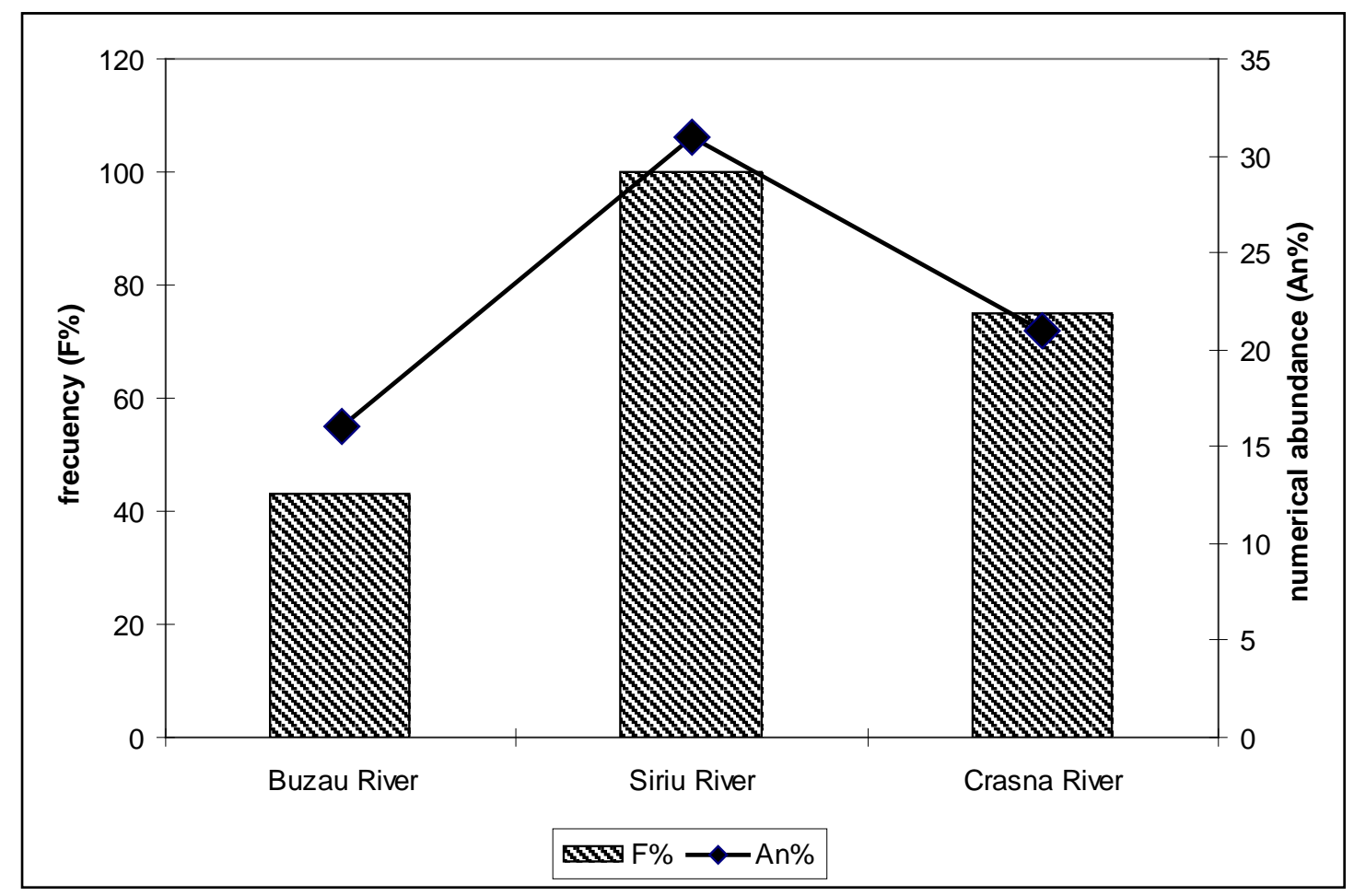

Figure 14: Cottus gobio frequency (F\%) and numerical abundance (An\%).

On the other hand, several studies (Charles et al., 2008; Kotlik et al., 2002) have been published estimating indices for minimum viable populations. So, the population viability of Barbus petenyi and Cottus gobio species in the investigated rivers are maintained if the criteria described below are met.

Criteria for Barbus petenyi's population viability are:

$>$ Criteria no. 1: the population density (D ind. $/ \mathrm{km}$ ) does not decline below a few tens of individuals in each one km length of river;

$>$ Criteria no. 2: the population numerical abundance (An\%) is higher than $10.1 \%$ for a favorable status;

$>$ Criteria no. 3: the population structure is characterized by at least three year-classes present in significant densities and at least $25 \%$ of the population should consist of $2+$ fish.

Criteria for Cottus gobio population viability are:

$>$ Criteria no. 1: the population density does not decline below one individual per $50 \mathrm{~m}^{2}$ of the river sector;

$>$ Criteria no. 2: the population numerical abundance (An\%) is higher than $5.1 \%$ for a favorable status;

$>$ Criteria no. 3: the population structure is characterized by at least three year-classes present in significant densities and at least $75 \%$ of the population should consist of $2+$ fish. 
Table 6: The fulfillment of criteria no. 1 and criteria no. 2 for Barbus petenyi's population viability.

\begin{tabular}{|c|c|c|c|c|c|c|c|}
\hline $\begin{array}{l}\text { Stations } \\
\text { code }\end{array}$ & Data & $\begin{array}{l}\text { The length } \\
\text { of fishing } \\
\text { stations (m) }\end{array}$ & $\begin{array}{l}\text { (ind./ } \\
\text { station) }\end{array}$ & $\begin{array}{c}\mathrm{D} \\
\text { (ind./km) }\end{array}$ & $\begin{array}{l}\text { An } \\
(\%)\end{array}$ & $\begin{array}{l}\text { Criteria } \\
\text { no. } 1 \\
\text { fulfill }\end{array}$ & $\begin{array}{c}\text { Criteria } \\
\text { no. } 2 \\
\text { fulfil }\end{array}$ \\
\hline \multirow{2}{*}{ B1 } & 05.06 & 90 & 9 & 100 & 60.16 & yes & yes \\
\hline & 10.09 & 90 & 4 & 44 & 30.43 & yes & yes \\
\hline B2a & 05.06 & 120 & 21 & 175 & 88.10 & yes & yes \\
\hline B2b & 05.06 & 120 & 5 & 42 & 27.08 & yes & yes \\
\hline B3 & 05.06 & 165 & 4 & 24 & 16.76 & yes & yes \\
\hline \multirow{2}{*}{ B4 } & 05.06 & 127 & 2 & 16 & 5.98 & yes & yes \\
\hline & 10.09 & 127 & 2 & 16 & 9.06 & yes & yes \\
\hline S1 & 05.0 & 120 & 0 & 0 & 0 & $\begin{array}{c}\text { no. } \\
\text { specific } \\
\text { area }\end{array}$ & $\begin{array}{c}\text { no. } \\
\text { specific } \\
\text { area }\end{array}$ \\
\hline \multirow[t]{2}{*}{ S2 } & 07.06 & 130 & 0 & 0 & 0 & $\begin{array}{c}\text { no } \\
\text { specific } \\
\text { area } \\
\end{array}$ & $\begin{array}{c}\text { no } \\
\text { specific } \\
\text { area }\end{array}$ \\
\hline & 11.09 & 130 & 2 & 15 & 33.33 & yes & yes \\
\hline C1 & 05.06 & 100 & 0 & 0 & 0 & $\begin{array}{l}\text { no. } \\
\text { specific } \\
\text { area }\end{array}$ & $\begin{array}{c}\text { no } \\
\text { specific } \\
\text { area }\end{array}$ \\
\hline \multirow[t]{2}{*}{ C2 } & 07.06 & 80 & 0 & 0 & 0 & $\begin{array}{c}\text { no } \\
\text { specific } \\
\text { area } \\
\end{array}$ & $\begin{array}{c}\text { no } \\
\text { specific } \\
\text { area }\end{array}$ \\
\hline & 11.09 & 80 & 0 & 0 & 0 & $\begin{array}{c}\text { no } \\
\text { specific } \\
\text { area }\end{array}$ & $\begin{array}{c}\text { no. } \\
\text { specific } \\
\text { area }\end{array}$ \\
\hline C3 & 05.06 & 88 & 0 & 0 & 0 & $\begin{array}{c}\text { no } \\
\text { specific } \\
\text { area } \\
\end{array}$ & $\begin{array}{c}\text { no } \\
\text { specific } \\
\text { area }\end{array}$ \\
\hline \multicolumn{2}{|c|}{ Total } & 1,567 & 49 & & & & \\
\hline & & & $\begin{array}{c}\mathrm{F}= \\
100 \% \\
\text { for } \\
\text { specific } \\
\text { areas }\end{array}$ & $\begin{array}{c}\text { D av. = } \\
59.57 \\
\text { ind./km }\end{array}$ & $\begin{array}{c}\text { An av. } \\
= \\
32.64 \\
\%\end{array}$ & $\begin{array}{l}100 \% \\
\text { fulfill }\end{array}$ & $\begin{array}{l}100 \% \\
\text { fulfill }\end{array}$ \\
\hline
\end{tabular}


Table 7: The fulfillment of this criteria no. 1 and criteria no. 2 for Cottus gobio's population viability.

\begin{tabular}{|c|c|c|c|c|c|c|c|}
\hline $\begin{array}{l}\text { Stations } \\
\text { code }\end{array}$ & Data & $\begin{array}{l}\text { The surface of } \\
\text { fishing stations } \\
\left(\mathrm{m}^{2}\right)\end{array}$ & $\begin{array}{l}\text { (ind./ } \\
\text { station) }\end{array}$ & $\begin{array}{c}\mathrm{D} \\
\text { (ind./ } \\
50 \mathrm{~m}^{2} \text { ) } \\
\end{array}$ & $\begin{array}{l}\text { An } \\
(\%)\end{array}$ & $\begin{array}{c}\text { Criteria } \\
\text { no. } 1 \\
\text { fulfill } \\
\end{array}$ & $\begin{array}{l}\text { Criteria } \\
\text { no. } 2 \\
\text { fulfill } \\
\end{array}$ \\
\hline \multirow{2}{*}{ B1 } & 05.06 & 250 & 0 & 0 & 0 & no & no \\
\hline & 10.09 & 250 & 5 & 1 & 13.04 & yes & yes \\
\hline B2a & 05.06 & 150 & 5 & 1.66 & 4.86 & yes & no \\
\hline B2b & 05.06 & 300 & 0 & 0 & 0 & no & no \\
\hline B3 & 05.06 & 600 & 7 & 1.16 & 20.35 & yes & yes \\
\hline \multirow{2}{*}{ B4 } & 05.06 & 200 & 3 & 0.25 & 20.51 & no & no \\
\hline & 10.09 & 200 & 0 & 0 & 0 & no & no \\
\hline S1 & 05.0 & 600 & 1 & 0.25 & 50.0 & no & no \\
\hline \multirow{2}{*}{ S2 } & 07.06 & 750 & 1 & 0.08 & 100.0 & no & no \\
\hline & 11.09 & 750 & 2 & 0.13 & 33.33 & no & no \\
\hline C1 & 05.06 & 100 & 0 & 0 & 0 & no & no \\
\hline \multirow[t]{2}{*}{$\mathrm{C} 2$} & 07.06 & 150 & 3 & 1.5 & 40.0 & yes & yes \\
\hline & 11.09 & 150 & 9 & 3 & 29.4 & yes & yes \\
\hline $\mathrm{C} 3$ & 05.06 & 60 & 1 & 0.33 & 35.71 & no & no \\
\hline \multicolumn{2}{|c|}{ Total } & 4,510 & 37 & & & & \\
\hline & & & $\begin{array}{c}\mathrm{F}= \\
64.28 \\
\%\end{array}$ & $\begin{array}{l}\text { D av. }= \\
0.66 \\
\text { ind./ } \\
50 \mathrm{~m}^{2} \\
\end{array}$ & $\begin{array}{c}\text { An av. } \\
= \\
24.8 \\
\% \\
\end{array}$ & $\begin{array}{c}35.71 \\
\% \\
\text { fulfill }\end{array}$ & $\begin{array}{c}28.57 \\
\% \\
\text { fulfill }\end{array}$ \\
\hline
\end{tabular}

\section{CONCLUSIONS}

In a first series of actions, EU member states designated SPAs and SCIs, based on the presence of habitats and species of community interest. They also embedded the BD and HD within their national legislations (Schoukens et al., 2007).

Currently, a second phase in the implementation process has already started. The EU member states assess the conservation status of all enlisted habitats and species to define corresponding conservation objectives and measures in each SCI so that they can be kept or brought into a favourable conservation status, and to set up monitoring schemes (Bottin et al., 2005; Förster et al., 2008). However, this process faces many important practical obstacles.

First, as data on the occurrence and abundance of habitats and species are generally scarce (Gaston et al., 2008), and financial resources to expand these data are limited, assessment of the actual conservation status is a challenging exercise that often leads to different approaches across member states (Opdam et al., 2009). Second, even if detailed data on the present status would be available, formulation of the conservation objectives is not a straightforward procedure. The surface area needed to attain (or maintain) a favourable conservation status for all targeted habitats and species, greatly exceeds the surface area designated by some member states as Natura 2000 sites. Hence, one must decide which habitats and species are of greatest interest in each of the individual 
SCIs. In addition, the HD stipulates that conservation objectives only need to be formulated and implemented within the boundaries of every individual SCI. However, the HD requires a favourable conservation status for habitats and species at the national or regional level (EC, 2005, 2006). Therefore, in the absence of a clear framework of national or regional conservation objectives, it will be difficult to estimate whether the aggregation of conservation objectives at the SCI level will meet the conditions for favourable conservation status at the national or regional level (Mehtälä and Vuorisalo, 2007).

Monitoring of conservation status is an obligation arising from Article 11 of the Habitats Directive for all habitats (as listed in Annex I) and species (as listed in Annex II, IV and V) of community interest. The main results of this monitoring have to be reported to the Commission every six years according to Article 17 of the directive. The conservation status of habitats and species should be evaluated at national level and biogeographic level. In the reporting format four classes of Conservation Status are used: Favourable Conservation Status (green), Unfavourable-Inadequate Conservation Status (amber), Unfavourable-Bad Conservation Status (red), Unknown Conservation Status (white).

The evaluation of conservation status of two fish species from the hydrographic network of PAs ROSCI0229 Siriu analyzing the frequency (F\%), numerical abundance (An\%) and density (D individuals $/ \mathrm{km}$ or individuals $/ \mathrm{m}$ ) criteria leads to the results show in tables 6 and 7 and synthesized below.

The Barbus petenyi species population fulfills the criteria no. 1 and no. 2 having a frequency of $100 \%$ for specific areas, an average population density of 59.57 individuals $/ \mathrm{km}$ and an average numerical abundance of $32.64 \%$. So, overall evaluation of population status is favorable, for areas where the species is characteristic, in this case Buzău River.

The Cottus gobio species population fulfills the criteria no. 1 for $35.71 \%$ and the criteria no. 2 for $28.57 \%$ having a frequency of $64.28 \%$ for all investigated areas, an average population density of 0.66 individuals $/ 50 \mathrm{~m}^{2}$ and an average numerical abundance of $24.8 \%$. So, overall evaluation of population status is medium favorable, for areas where the species is characteristic, in this case Buzău River and its tributaries, river Crasna and river Siriu. 


\section{ACKNOWLEDGEMENTS}

The authors wish to thank to the S. C. Multidimension SRL team who provided the logistic for this project. 


\section{REFERENCES}

1. Bănărescu P., 1964 - Pisces: Osteichthys (Peşti Ganoizi şi Osoşi), Editura R.P.R. Academy, Bucharest, 13, 962. (in Romanian)

2. Bănărescu P., 1968 - Lista revizuită a peștilor din România, Buletinul Institutului de Cercetări și Proiectări Piscicole, XXVII, 3, 53-61. (in Romanian)

3. Bănărescu P. and Bănăduc D., 2007 - Habitats Directive (92/43/EEC) fish species (Osteichthyes) on the Romanian territory, Acta Ichtiologica Romanica, II, 43-78.

4. Cantarello E. and Newton A., 2008 - Towards cost-effective indicators to maintain Natura 2000 sites in favourable conservation status. Preliminary results from Cansiglio and New Forest, Forest, 1, 75-80.

5. Charles S., Subtil F., Kielbassa J. and Pont D., 2008 - An individual-based model to describe a bullhead population dynamics including temperature variations, Ecological modelling, 215, 377392.

6. Chaumota A., Milionia N., Abdolib A., Pont D. and Charles S., 2006 - First step of a modelling approach to evaluate spatial heterogeneity in a fish (Cottus gobio) population dynamics, Ecological modelling, 197, 263-273.

7. Cowx I. G. and Welcomme R. L., 1998 - Rehabilitation of Rivers for Fish, Blackwell Science, Oxford, UK, 204.

8. Curtean-Bănăduc A. and Florescu F. (eds), 2007 - Romanian NATURA 2000 NGO Coalition contribution for the SCIs designation, Editura Alma Mater Sibiu, ISBN 978-973-632-402-4, 211.

9. Fischer S. and Kummer H., 2000 - Effects of residual flow and habitat fragmentation on distribution and movement of bullhead (Cottus gobio L.) in an alpine stream, Hydrobiologia, 422/423, 305-317.

10. Fish base, 2011.

11. Florea L., 2011 - The distribution of the conservative fish species in the Natura 2000 network from Romania, Studii şi cercetări ştiințifice, Seria: Biologie, XXI, Editura Alma-Mater, Bacău, ISSN 1224-919X, 1-7.

12. Fontaine B., Bouchet P., Van Achterberg K., Alonso-Zarazaga M. A., Araujo R., Asche M., Aspöck U., Audiso P., Aukema B., Bailly N., Balsamo M., Bank R. A., Barnard P., Belfiore C., Bogdanowicz W., Bongers T., Boxshall G., Burckhardt D., Camicas J.-L., Chylarecki P., Crucitti P., Deharveng L., Dubois A., Enghoff H., Faubel A., Fochetti R., Gargominy O., Gibson D., Gibson R., López M. S. G., Goujet D., Harvey M. S., Heller K.-G., Van Helsdingen P., Hoch H., De Jong H., De Jong Y., Karsholt O., Los W., Lundqvist L., Magowski W., Manconi R., Martens J., Massard J. A., Massard-Geimer G., Mcinnes S. J., Mendes L. F., Mey E., Michelsen V., Minelli A., Nielsen C., Nafría J. M. N., Van Nieukerken E. J., Noyes J., Pape T., Pohl H., De Prins W., Ramos M., Ricci C., Roselaar C., Rota E., Schmidt-Rhaesa A., Segers H., Strassen R. Z., Szeptycki A., Thibaud J.-M., Thomas A., Timm T., Van Tol J., Vervoort W. and Willmann R., 2007 - The European Union's 2010 target: putting rare species in focus, Biological Conservation, 139, 167-185.

13. Gaston K. J., Jackson S. E., Nagy A., Cantu-Salazar L. and Johnson M., 2008 - Protected areas in Europe - principle and practice, Annals of the New York Academy of Sciences, 1134, 97-119.

14. Gosselin M., Petts G. E. and Maddock I. P., 2010 - Mesohabitat use by bullhead (Cottus gobio), Hydrobiologia, 652.1 , 299-310.

15. Hanfling B. and Brandl R., 1998 - Genetic variability, population size and isolation of distinct populations in the freshwater fish Cottus gobio L, Molecular Ecology, 7, 1625-1632.

16. Hanfling B. and Weetman D., 2006 - Concordant Genetic Estimators of Migration Reveal Anthropogenically Enhanced Source-Sink Population Structure in the River Sculpin, Cottus gobio, Genetics, 1487-1501.

17. Iftime A., 2004 - Preliminary data on the distribution of two twin species of the genus Barbus (Pisces: Teleostei: Cyprinidae) in southern Romania, Travaux du Museum National d'Histoire Naturelle “Grigore Antipa”, București, XLVII, 263-268. 
18. Iojă C. I., Pătroescu M., Rozylowicz L., PopescuV. D. and Vergheleţ M., 2010 - The efficacy of Romania's protected areas network in conserving biodiversity, Biological Conservation, 143, 2468-2476.

19. Knaepkens G., Bruyndoncx L., Bervoets L. and Eens M., 2002a - The presence of artificial stones predicts the occurrence of the European bullhead (Cottus gobio) in a regulated lowland river in Flanders (Belgium), Ecology of Freshwater Fish, 11, 203-206.

20. Knaepkens G., Knapen D., Bervoets L., Hanfling B., Verheyen E. and Eens M., 2002b - Genetic diversity and condition factor: a significant relationship in Flemish but not in German populations of the European bullhead (Cottus gobio L.), Heredity, 89, 280-287.

21. Knaepkens G., Bervoetsb L., Verheyenc E. and Eens M., 2004 - Relationship between population size and genetic diversity in endangered populations of the European bullhead (Cottus gobio): implications for conservation, Biological Conservation, 115, 403-410.

22. Kotlik P., Tsigenopoulos C., Rab P.and Berrebi P., 2002 - Two new Barbus species from the Danube River basin, with redescription of B. petenyi (Teleostei: Cyprinidae), Folia zoologica, 51, 3, 227-240.

23. Legalle M., Santoul F., Figuerola J., Mastrorillo S. and Cereghino R., 2005 - Factors influencing the spatial distribution patterns of the bullhead (Cottus gobio L., Teleostei Cottidae): a multiscale study, Biodiversity and Conservation, 14, 1319-1334.

24. Maiorano L., Falcucci A. and Boitani L., 2008 - Size-dependent resistance of protected areas to land-use change, Proceedings of the Royal Society B, 275, 1297-1304.

25. Margules C. R. and Pressey R. L., 2000 - Systematic conservation planning, Nature, 405, 243253.

26. Mehtälä J. and Vuorisalo T., 2007 - Conservation policy and the EU Habitats Directive: Favourable conservation status as a measure of conservation success, European Environment, 17, 363-375.

27. Nalbant T., 2003 - Checklist of the Fishes of Romania, Part One: Fresh and Saltwater Fishes, Research Studies and Biology, 8, 122-127.

28. Nielsen S. E., Bayne E. M., Schieck J., Herbers J. and Boutin S., 2007 - A new method to estimate species and biodiversity intactness using empirically derived reference conditions, Biological Conservation, 137, 403-414.

29. Pont D., Hugueny B. and Oberdorff T., 2005 - Modelling habitat requirement of European fishes: do species have similar responses to local and regional environmental constraints, Canadian Journal of Fisheries and Aquatic Sciences, 62, 1, 163-173.

30. Pullin A. S., Baldi A., Can O. E., Dieterich M., Kati V., Livoreil B., Lovei G., Mihok B., Nevin O., Selva N. and Sousa-Pinto I., 2009 - Conservation focus on Europe: major conservation policy issues that need to be informed by conservation science, Conservation Biology, 23, 818824.

31. Sax D. F. and Gaines S. D., 2008 - Species invasions and extinction: The future of native biodiversity on islands, Proceedings of the National Academy of Sciences of the USA, 105, 11490-11497.

32. Seeuws P., Meire P. and Verheyen R. F., 2005 - Microhabitat use and preferences of the endangered Cottus gobio in the River Voer, Belgium, Journal of Fish Biology, 67, 4, 897-909.

33. Thuiller W., Lavorel S., Araújo M. B., Sykes M. T. and Prentice I. L., 2005 - Climate change threats to plant diversity in Europe, Proceedings of the National Academy of Sciences of the USA, 102, 8245-8250.

34. Utzinger J., Roth C. and Peter A., 1998 - Effects of environmental parameters on the distribution of bullhead (Cottus gobio) with particular consideration of the effects of obstructions, Journal of Applied Ecology, 35, 882-892.

35. Vlach P., Dusek J. and Moravec P., 2005 - Fish assemblage structure, habitat and microhabitat preference of five fish species in a small stream, Folia Zoologica, 54, 4, 421-431. 
36. Anonymous, 2009 - Natura 2000 Barometer - Update November 2009, Natura 2000 European Commission Nature and Biodiversity Newsletter, 27, 8-9.

37. EEA (European Environment Agency), 2006 - Progress towards halting the loss of biodiversity by 2010, EEA report, 5/2006, Luxembourg.

38. MEF/NAE (Ministry of Environment and Forest/National Agency of Environment), 2009 Nature conservation and biodiversity, biosafety, National environmental raport, 160-218.

39. MESD (Minister of Environment and Sustainable Development), 2007 - OM 1964 - The constitute of the natural protected area of Community importance as part integral to the European ecological network Natura 2000 Romanian, 1-1315.

40. NARW (National Administration "Romanian Waters", 2009 - Management Plan River of space - Ialomița Buzău,10-25.

41. http://www.rowater.ro/dabuzau/Planul\% Planul de Management al Spațiului Hidrografic Buzău, pdf (accessed at 16.07.2013). 